\title{
NON- GOVERNMENTAL ORGANISATIONS FOR WOMEN IN VELLORE DISTRICT
}

\author{
V.Priya ${ }^{1}$, Dr. M. Palani² \\ ${ }^{1}$ Assistant professor in History, Muthurangam Govt. Arts College, Vellore - 632002 \\ ${ }^{2}$ Assistant professor in History, Govt. Arts College for Men, Nandanam, Chennai - 600035
}

\begin{abstract}
The paper summarizes the study of the development and empowerment of women with a special reference to Non - Governmental Organizations in Vellore district of Tamil Nadu. The study intends to identify the role and participation of various NGOs by actively initiating many welfare programs and income generating projects for rural women. The work of the study progressed with the data collected from NGOs and SHGs women of Vellore district of Tamil Nadu.
\end{abstract}

Keywords: NGOs - Women Empowerment - Vellore, Tamil Nadu

\section{INTRODUCTION: -}

"Have faith and confidence in yourself and use your complete potential in achieving your dreams".Vijayalakshmi Bidari. It is an absolute truth and proved beyond any doubt by SHARE, CODES, SMASH, RUHSA, were Non - Governmental Organizations exclusively run by and for rural women. By their sincere efforts and hard work many challenges have been faced confidently and also gained remarkable success in their lives.

There are more than 150 NGOs, functioning in Vellore district of Tamil Nadu. Few Institutions render valuable and remarkable service, exclusive for women in rural areas. The Institutions which served most satisfactorily and earned reputation in Vellore town are taken into consideration for the study.

\section{OBJECTIVE OF THE STUDY:}

To analyze the impact of women joining NGOs through SHGs

To explore the driving changes which constitute the women empowerment with respect to NGOs

$>\quad$ To validate the instrumental changes among rural women

\section{METHODOLOGY:}

3.1 Research: Exploratory research type has been adopted by the researcher with an intension to gain information on this issue in various perspective.

3.2 Data source: The researcher utilized both the primary and secondary data. The primary data were collected from the respondents using self - interviews and preparing questionnaires. The secondary data includes various research papers, articles retrieved using online database. The questionnaires framed by the researcher was in vernacular language (Tamil) using back translated method.

\section{NON- GOVERNMENTAL ORGANIZATIONS:}

\subsection{SHARE (SELF-HELP ASSOCIATION FOR RURAL EDUCATION AND EMPLOYMENT) OBJECTIVE:}

The objective of this society is to bring in all round development to the neglected and down trodden section of the women population in the villages, having initiated activities by empowering women in the line of solidarity. SHARE strongly believes that true development lies in the women groups and communities, which should take all decisions concerning their lives. Self - help concept is the strength of this Organization.

PROGRAMS:

SHARE implements many innovative programs for women in rural areas to mitigate their sufferings and to face confidently the challenges in day to-day life. It also readily comes forward to help the needy persons. 


\section{INNOVATIVE PROGRAMMES}

- Maintaining Bal wadi for kids,

- Creating Awareness - Motivation programs,

- Forming Self-Help Groups,

- Implementing Skill development training,

- Utilizing Human Resource Development.



\section{INCOME GENERATING PROJECTS:}

SHARE invariably buys raw materials locally available and produces variety of fancy and utility products as well as home need things. The main products are:

1.Palm leaf Basketry

2.Sisal Fiber Work

3.Handloom Weaving

4. Wool Carpet Weaving

5.Dairy products

6.Micro-Enterprises etc. (assembling electronic components)

SHARE's hard work, and best presentation in manufacturing variety of products earned a good profit. Gist of its annual turnout is furnished below:

\begin{tabular}{|l|l|}
\hline The total cost of production & Rs.25, 00,000 \\
\hline Sale Value of the products & Rs.30, 00,000 \\
\hline Domestic sales value & $25 \%$ \\
\hline Export sales value & $75 \%$ \\
\hline
\end{tabular}

\subsection{CODES (THE COMMUNITY DEVELOPMENT SOCIETY)}

CODES is a registered Society functioning independently and a Non-governmental Voluntary Organization involved in many community development activities during the last 23 years. It is located at Bagayam, in Vellore town. Originally, CODES has taken over the management of CHAD'S income generating activities. It coordinates the operations from the buying of raw materials to the marketing of the finished goods. It provides training in some trades and also makes arrangement for training in some other handicrafts. 


\section{International Advanced Research Journal in Science, Engineering and Technology \\ Impact Factor $7.105 \div$ Vol. 9, Issue 1, January 2022 \\ DOI: 10.17148/IARJSET.2022.9145}

\section{PROGRAMMES AND FUNCTIONS OF CODES:}

\section{Day Care Centres:}

CODES has been running Day Care Centres sponsored by Central Social Welfare Board, under its direct supervision. There are about 500 children getting the benefit of these 19 centres. Working mothers are greatly benefited by this program.

CHAD provides health care for these children and health awareness to the parents. CMC also provides special medical care to prevent EYE, EAR, and NOSE \& THROAT infections among children.

\section{Housing Project:}

Financed by Habitat for Humanity, CODES was able to provide interest free loans to 5 needy families for construction of houses. Mr. Peter Samuel of Habitat for Humanity inaugurated the program on 6.1.2000. Identification of more suitable families is underway and our sister organization SHARE helps in screening the applicants.

\subsection{SMASH (Small and Marginal Agriculturists Store House)}

This project started in 1995 has been functioning well. 20 farmers had stored 60 tons of turmeric in the storehouse in this financial year Small \& Marginal farmers are thus able to get optimum price for their produce instead of being exploited by middlemen.

\section{WASTE DISPOSAL PROJECT:}

Sponsored by CMC, a program of waste disposal \& manure production has been functioning since 1997. Through this program wastes from CMC Campus are collected and disposed appropriately by separating them into items for manure, and items to be disposed off by fire \& non-bio gradable for landfills. 4 members, including one physically disabled person work in this project.

\section{WOMEN'S STEEL FABRICATION UNIT:}

Fabrication work is a very difficult job suitable for men-folk only. Cutting of iron sheets, bending, welding, grinding all require strong physical strength, and this job also involves considerable risk to life. But young women working in this unit boldly face this challenge; they deserve a great appreciation. Steel products are manufactured in this unit. About $50 \%$ of orders are secured from CMC \& H. Products like Steel Cupboards, cots, tables, filing cabinets are produced in this unit. In addition to this the unit undertakes repair and maintenance work for CMC.

\subsection{RUHSA: (RURAL UNIT FOR HEALTH AND SOCIAL AFFAIRS).}

RUHSA is a Non-Governmental voluntary social organization founded by CMC Hospital Vellore. It was set up in 1977 as an integrated program of health care and socio-economic development It is located in the K.V.Kuppam Block in Vellore District. K.V.Kuppam is a village considered to be one of the most socio-economical backward regions in Tamil Nadu. Dr.Daleep S.Mukarji was the first Director of the organization. Under this program, there are six functional sections dealing with Health, Social Education development, Agriculture, Animal Husbandry, CERT (Consultancy, Evaluation, Research and Training) and administration. All the six sections coordinate and function with a spirit of dedication for the social and economic progress of the population in the K. V. Kuppam area.

\section{OBJECTIVES AND PERFORMANCE:}

RUHSA's inspiration and philosophy was a belief that health and development are interlinked and it emphasizes the individual health development to encourage community building and to provide avenues for people's participation in their own development and progress RUHSA has pivoted itself on five basic models of collective leadership.

RUHSA has also developed close relation with the Government and other development agencies functioning in the blocks, in order to avoid working in competition with other agencies.

\section{INITIATIVE ON BEHALF OF WOMEN:}

To convert women from being marginal beneficiaries, and to make them fit for development, has been the main thrust of RUHSA's initiative on behalf of women. Making women fit for the development work was not so easy. One of RUHSA's earliest difficulties in setting up activities of women was its inability to field female staff on a sustained basis. Failure in the early years in engaging and involving women in Health and Development process was successfully over come at present.

The new technique adopted was education and economic betterment of women which can make a significant contribution to the health of families and individuals. The revised approach would focus on women's role in income generation and education and training activities. 


\section{International Advanced Research Journal in Science, Engineering and Technology \\ Impact Factor $7.105 \div$ Vol. 9, Issue 1, January 2022 \\ DOI: 10.17148/IARJSET.2022.9145}

Yet another praise worthy program of RUHSA is income generating activities and training to give women the requisite productive skills. Hundreds of women have been successfully trained in various trades such as making brooms, envelopes, agarbattis, potato chips, etc., and their skills also have been tried in repairing of radio and bicycle, tailoring, weaving and cane craft.

\section{CONCLUSION:}

The study shows that the valuable services rendered by the various NGOs in Vellore district towards empowering women in rural areas. It is a fact that after entering into NGOs through SHGs the women are economically and Socially empowered and enriched.

\section{REFERENCES:}

1. R.Karuppannan, SSRN 2513715, 2014 - Title: Role of NGOs in micro finance through SHGs - A study in Vellore district of Tamil Nadu.

2. B. Nagaraj, N. Sundaram, 2017 - Title: Effectiveness of SHGs towards the empowerment of women in Vellore district, Tamil Nadu.

3. S. Kamaraj, A. Pandu - Journal of Management and development studies, 2013 - Title: Job satisfaction of women entrepreneurs with special reference to SHGs of Vellore district.

4. AA Mir - Economic \& Social Dimensions: Engine for Growth, 2019 - Title: Non-Governmental Organizations: An Engine for women Empowerment.

5. AC Mohan - International journal of management and development, 2015 - Title: Role of NGOs in Microfinance through SHGs - A study in Kanchipuram district of Tamil Nadu.

6. A study on women entrepreneurship in rural Tamil Nadu with special reference to Vellore district, P. Chennakrishnan - Management, 2019, shanlaxpublications.com

7. Role of NGO (CRHSE) in establishing brand identity of SHGs products in rural markets R. Amudha, A. Dhanalakshmi, AMBER, 2010, ischolar.info

8. Role of NGOs in public health, DJ Ghongade - Healthy Society for Healthy Nation - researchgate.net

9. Empowerment of women through SHGs in Vellore district of Tamil Nadu - M. Thenaruvi, International journal for Economics and Business Management - 2017, pp. 105-116.

10. D. Rajasekar - editor, Decentralized govt. \& NGOs.

11. Tamil Nadu women Development project in Vellore district.

12. K.P. Kumaran, SHGs an alternative to institutional credit to the poor, journal of rural development volume 16 (3), 1997, pp. 515-530.

13. Lalitha. N \& Nagarajan. B.S, SHGs in Rural development, Delhi, 2002, pp. 3, 5, 6, 8.

14. Anubhav, experience in community health, publication, No.7, P.1,5,12,19,20,22,30.

15. CODES - Annual return 2000-01 P.1 